\title{
PENGARUH KOMPETENSI KEPRIBADIAN GURU TERHADAP PEMBENTUKAN KARAKTER SISWA DI SD NEGERI MARGOREJO VI/524 SURABAYA
}

\author{
Indah Tri Agustin ${ }^{1}$, Nafiah $^{2}$ \\ Universitas Nahdlatul Ulama Surabaya \\ Indahagustin553@gmail.com \\ nefi_23@unusa.ac.id
}

\begin{abstract}
The influence of Teacher's Personality Competency to Students' Character Building of Margorejo VI/524 of Surabaya State Elementary School. Teacher's personality competency is one of the competencies that must be mastered by an educator, with the mastery of personality competencies it will facilitate the performance of the teacher in guiding and carrying out tasks as a professional educator.This study aims to find out how the personality competencies of teachers; the character of students; and anyinfluence of teacher personality competencies on the formation of student character in Margorejo Elementary School VI/524 Surabaya. This research is quantitative research. In this study the population amounted to 299 students taken from class IV-VI, the researcher used the study sample. Sample was 171 students. Data collection by questionnaire. The validity instrument used the SPSS program assistance. The reliability index was 0.837 for the teacher's personality competency questionnaire. The data analysis technique was percentage descriptive analysis techniques and Spearman Rank correlation analysis. The results showed that the teacher's personal competence in Margorejo VI/524 Elementary School Surabaya was $92.82 \%$, which means in very good criteria, while the character of integrity, religious, nationalist, independent, and cooperation owned by students amounted to $84.34 \%$, which means in very good criteria. While the correlation between teacher personality competency $(\mathrm{X})$ towards the formation of student character $(\mathrm{Y})$ has a correlation coefficient $(r)=0.436$ which means that it is low correlated. Based on this study, it can be concluded that $\mathrm{H} 1$ is accepted, which means that there is an influence between the teacher's personal competency towards the formation of student character in Margorejo VI/524 Surabaya Elementary School.
\end{abstract}

Keywords: Teacher Personality Competence, Student Character.

\begin{abstract}
Abstrak
Pengaruh Kompetensi Kepribadian Guru terhadap Pembangunan Karakter Siswa Margorejo VI / 524 Sekolah Dasar Negeri Surabaya. Kompetensi kepribadian guru adalah salah satu kompetensi yang harus dikuasai oleh seorang pendidik, dengan penguasaan kompetensi kepribadian itu akan memudahkan kinerja guru dalam membimbing dan melaksanakan tugas sebagai pendidik profesional. Penelitian ini bertujuan untuk mengetahui bagaimana kompetensi kepribadian guru; karakter siswa; dan pengaruh kompetensi kepribadian guru terhadap pembentukan karakter siswa di Sekolah Dasar Margorejo VI / 524 Surabaya. Penelitian ini adalah penelitian kuantitatif. Dalam penelitian ini populasi berjumlah 299 siswa yang diambil dari kelas IV-VI, peneliti menggunakan sampel penelitian. Sampel adalah 171 siswa. Pengumpulan data dengan kuesioner. Instrumen validitas menggunakan bantuan program SPSS. Indeks reliabilitas adalah 0,837
\end{abstract}


untuk kuesioner kompetensi kepribadian guru. Teknik analisis data adalah teknik analisis deskriptif persentase usia dan analisis korelasi Rank Spearman. Hasil penelitian menunjukkan bahwa kompetensi pribadi guru di SD Negeri Margorejo VI / 524 Surabaya adalah 92,82\%, yang berarti dalam kriteria sangat baik, sedangkan karakter integritas, agama, nasionalis, mandiri, dan kerja sama yang dimiliki siswa sebesar 84,34\%, yang artinya dalam kriteria yang sangat baik. Sedangkan korelasi antara kompetensi kepribadian guru $(\mathrm{X})$ terhadap pembentukan karakter siswa $(\mathrm{Y})$ memiliki koefisien korelasi $(r)=0,436$ yang artinya berkorelasi rendah. Berdasarkan penelitian ini, dapat disimpulkan bahwa $\mathrm{H} 1$ diterima, yang berarti bahwa ada pengaruh antara kompetensi pribadi guru terhadap pembentukan karakter siswa di Margorejo VI / 524 Sekolah Dasar Surabaya.

Keywords: Teacher Personality Competence, Student Character.

\section{PENDAHULUAN}

Kompetensi guru merupakan penguasaan pengetahuan keguruan dan pemilikan keterampilan serta kemampuan sebagai guru dalam melaksanakan tugasnya (Djamarah, 2012: 34). Berbagai aspek kepemilikan guru tersebut tentunya akan mempermudah kinerja guru dalam membimbing dan melaksanakan tugasnya sebagai seorang tenaga pendidik yang profesional.

Salah satu kompetensi yang harus dimiliki guru adalah kompetensi kepribadian. Kepribadian merupakan aspek penting yang menentukan keberhasilan guru dalam melaksanakan tugas sebagai pendidik, hal ini karena kepribadian merupakan keseluruhan dari individu yang terdiri dari unsur psikis dan fisik (Djamarah, 2012: 58).

Sebagai seorang pendidik sudah seharusnya memiliki kepribadian yang baik guna menjadi teladan dan panutan bagi peserta didik. Oleh karena itu seorang guru harus memiliki standar kompetensi kepribadian guru yang harus dipenuhi yakni tanggung jawab, berwibawa, mandiri, dan disiplin. Guru harus mampu menegakkan nilai-nilai kejujuran dan keadilan, sebagai pribadi yang bertanggung jawab guru harus mengetahui dan memahami nilai, norma, moral, sosial, serta guru harus berusaha untuk menjalankan dan mentaati norma yang berlaku. Selain itu guru juga harus bertanggung jawab terhadap segala tindakan yang dilakukannya (Rochman \& Gunawan, 2012: 40). Bila diperhatikan tugas dan kewajiban sebagai seorang pendidik cukuplah berat, selain dituntut untuk pintar dalam segi wawasan pengetahuan (knowledge), sebagai seorang pendidik juga harus dituntut untuk menunjukkan kepribadian yang baik dalam kehidupannya. Dengan demikian sebagai seorang pendidik dituntut untuk seprofesional mungkin dalam melaksanakan tugasnya.

Berdasarkan penelitian yang dilakukan (Tamsil, Syafiq, \& Savira, 2011: 63-74) menunjukkan bahwa $91 \%$ siswa pernah mengalami tindakan kekerasan yang dilakukan oleh seorang guru, tindakan tersebut antara lain seperti kekerasan verbal, psikologis, maupun kekerasan fisik.

Munculnya problematika tersebut tentunya timbul karena adanya ketidakmampuan seorang pendidik dalam mengemban dan menjalankan kompetensi yang dimilikinya secara profesional, jika 
seorang pendidik melakukan tugas dan kewajiban secara profesional maka berbagai problematika tersebut tidak akan terulang kembali. Melihat berbagai problematika tersebut maka pendidik perlu memperbaiki tingkat keprofesionalismenya dalam menjalankan empat kompetensi yang harus dikuasainya terutama dalam segi kompetensi kepribadian agar terciptanya pendidikan yang berkulitas sesuai dengan tujuan pendidikan nasional. Kompetensi kepribadian guru dan karakter siswa merupakan satu kesatuan yang tidak dapat dipisahkan, hal ini karena karakter siswa merupakan bagian yang mencerminkan kepribadian seorang guru.

Menurut Suyanto dalam (Azzet, 2014: 16) karakter adalah cara berpikir dan berperilaku yang menjadi ciri khas setiap individu untuk hidup dan berkerja sama, baik dalam lingkup keluarga, masyarakat, bangsa, dan negara. Sebagai seorang individu yang berkarakter sudah seharusnya dapat mempertanggungjawabkan setiap tindakan dan keputusan yang dibuatnya, dengan demikian maka individu tersebut dapat dikatakan memiliki karakter yang baik. Jika dikaitkan dengan pendidikan maka setiap siswa dikatakan memiliki karakter baik apabila seorang siswa mampu menunjukkan cara berpikir dan berperilaku yang baik dalam kehidupannya, hal ini karena siswa dinilai memiliki karakter baik dapat dilihat dari cara berperilaku maupun cara berpikir yang dimilikinya.

Sedangkan menurut Lorens Bagus dalam (Kurniawan, 2017: 28) mendefenisikan bahwa karakter adalah sebagian dari jumlah seluruh ciri pribadi yang meliputi perilaku, kebiasaan, kesukaan, ketidaksukaan, kemampuan, kecenderungan, potensi, nilai-nilai, dan pola-pola pemikiran.

Dari beberapa defenisi tersebut dapat disimpulkan bahwa karakter adalah suatu ciri khas perilaku atau sifat yang dimiliki seorang individu yang dapat membedakan dirinya dengan yang lain guna mempengaruhi seorang individu tersebut dalam berpikir, bertindak, dan berprilaku. Sehingga karakter dapat mencerminkan kepribadian individu disetiap tindakan yang dilakukannya dalam kehidupan.

Tindakan dan penyimpangan yang dilakukan oleh seorang guru tentunya akan berpengaruh terhadap karakter seorang siwa, hal ini karena guru merupakan panutan dan teladan bagi siswa. Hal ini sejalan dengan semboyan yang dikemukakan oleh Ki Hajar Dewantoro yaitu "Ing Ngarso Sung Tulodo, Ing Madyo Mangun Karso, Tut Wuri Handayani" yang maknanya yaitu di depan memberi teladan, di tengah berbuat keseimbangan, dan di belakang memberi dorongan (Hasbullah, 2015: 268).

Dengan demikian segala sesuatu yang dilakukan guru maka siswa akan berusaha untuk mencontoh dan menirukannya. Oleh karena itu untuk membentuk karakter siswa sesuai dengan tujuan pendidikan nasional, maka seorang guru harus berupaya untuk membentuk dan menjalankan kompetensi kepribadian yang dimiliki terlebih dahulu. Agar siswa dapat mencontoh kompetensi kepribadian yang dimiliki oleh guru.

Berdasarkan penelitian sebelumnya yang dilakukan oleh Widyaningsih yang berjudul Pengaruh Kompetensi Kepribadian Guru terhadap Disiplin Siswa Kelas V SD Se-Gugus 1 Sidodarum Goden Sleman Tahun Ajaran 2015/2016 menunjukkan bahwa antara kompetesi 
kepribadian guru dan disiplin siswa terdapat pengaruh positif dan signifikan, hal tersebut dapat ditunjukkan dari besarnya pengaruh kompetensi kepribadian guru terhadap disiplin siswa sebesar $2.7 \%$, sedangkan $97,3 \%$ berasal dari faktor lain yang tidak terdapat dalam penelitian ini (Widyaningsih, 2015: 1-6). Dari penelitian tersebut menunjukkan bahwa kompetensi kepribadian guru memiliki pengaruh terhadap siswa terutama dalam pengaruh sikap disiplin siswa.

Sedangkan penelitian yang dilakukan oleh Saepul Anwar yang berjudul Studi Realitas Kompetensi Kepribadian Guru Pendidikan Agama Islam Sekolah Menengah Atas di Kabupaten Bandung. Untuk mengetahui kompetensi kepribadian tersebut telah dimiliki guru maka dalam penelitian ini mencoba mengukur aspek integritas, kemampuan intrapersonal, kepemimpinan, kestabilan emosi, dan keterbukaan yang dimiliki guru pendidikan agama Islam. Dari seluruh aspek tersebut memperoleh rata-rata nilai 3,8 berada pada interval 3,3<X $\leq 4$ yang berarti dalam kategori tinggi (Anwar, 2011: 145-159). Dengan demikian kompetensi kepribadian guru Pendidikan Agama Islam menunjukkan kecenderungan ke arah yang positif, kecenderungan tersebut tentunya akan menimbulkan dampak positif pula bagi proses pelaksanaan pendidikan.

Dari penelitian-penelitian terdahulu menunjukkan bahwa kompetensi kepribadian guru memiliki nilai-nilai positif bagi siswa maupun bagi pendidik itu sendiri, hal itu dapat ditunjukkan dari semakin baik kompetensi kepribadian yang dimiliki guru maka akan memiliki pengaruh serta sumbangsih besar terhadap keberhasilan suatu pendidikan. Peneliti mencoba untuk meneliti lebih detail mengenai pengaruh dari kompetensi kepribadian guru terhadap pembentukan karakter siswa.

Berdasarkan observasi studi pendahuluan menunjukkan bahwa SD Negeri Margorejo VI/524 Surabaya memiliki potensi besar untuk membentuk karakter siswa melalui kepribadian yang ditampilkan guru dalam lingkungan sekolah, hal ini terbukti dari kebijakan yang ditetapkan pihak sekolah yang tertuang di dalam visi dan misinya. Tetapi sebagian guru kurang menunjukkan kompetensi kepribadian yang baik, hal tersebut terlihat dari perilaku ketika guru saling tunjuk untuk melakukan ibadah bersama dengan siswa. Selain itu kurangnya kedisiplinan guru yang terlihat dari sebagian guru terlambat tidak tepat waktu datang ke sekolah. Sedangkan karakter siswa di SDN Margorejo VI/524 Surabaya dirasa peneliti kurang baik, hal tersebut terlihat dari kebiasaan siswa yang suka mengolok-olok, datang ke sekolah terlambat, dan sebagian siswa kurang sadar untuk melakukan ibadah. Berbagai permasalahan tersebut dapat terlihat ketika peneliti melakukan pengamatan secara langsung ketika berada di SD Negeri Margorejo VI/524 Surabaya.

Berdasarkan permasalahan di atas, peneliti ingin meneliti "Pengaruh Kompetensi Kepribadian Guru Terhadap Pembentukan Karakter Siswa di SD Negeri Margorejo VI/524 Surabaya".

Berdasarkan uraian dan permasalahan yang telah dikemukakan, maka diperoleh rumusan masalah:

1. Bagaimana kompetensi kepribadian guru di SD Negeri Margorejo VI/524 Surabaya? 
2. Bagaimana karakter siswa di SD Negeri Margorejo VI/524 Surabaya?

3. Bagaimana pengaruh kompetensi kepribadian guru terhadap pembentukan karakter siswa di SD Negeri Margorejo VI/524 Surabaya?

\section{METODE PENELITIAN}

Desain penelitian yang digunakan dalam penelitian ini menggunakan metode penelitian kuantitatif non eksperimen. Pada penelitian ini menggunakan jenis kuantitatif korelasional yang digunakan untuk mengetahui pengaruh terhadap suatu variabel oleh variabel lain. Sehingga penelitian ini bertujuan untuk mengetahui kesimpulan pasti dari adanya "Pengaruh Kompetensi Kepribadian Guru Terhadap Pembentukan Karakter Siswa di SD Negeri Margorejo VI/524 Surabaya".

Penelitian ini dilakukan di SD Negeri Margorejo VI/524 Surabaya yang beralamatkan di Jl. Taman Jemursari No.4 Rt 02 Rw 10 Kelurahan Jemurwonosari Kecamatan Wonocolo Kota Surabaya.

Populasi pada penelitian ini penelitian yaitu berjumlah 299 responden diambil dari kelas IV-VI, karena jumlah responden $\geq 100$ maka peneliti menggunakan sampel penelitian, adapun teknik pengambilan sampel menggunakan rumus Slovin sehingga diperoleh jumlah sampel penelitian ini yaitu 171 responden.

Teknik pengumpulan data yang digunakan dalam penelitian ini yaitu menggunakan angket/kuesioner bersifat tertutup. Sedangkan instrumen dalam penelitian ini berupa angket yang dibuat dalam bentuk butir-butir pertanyaan yang dibuat sesuai dengan indikator yang akan diukur, sehingga dapat terarahkan oleh tujuan masalah dan hipotesis penelitian.
Semua butir pertanyaan pada angket harus dijawab oleh responden. Adapun Instrumen penelitian yang disusun berdasarkan kisi-kisi intrumen kompetensi kepribadian guru (X) dan karakter siswa (Y).

Pada penelitian ini skala pengukuran variabel menggunakan skala pengukuran Likert dengan menggunakan empat alternatif jawaban (a, b, c, atau d) Pengukuran setiap variabel dilakukan dengan membuat lembaran angket. Lembaran angket yang terkumpul disusun berdasarkan urutan data yang diperlukan dan jawaban yang tepat menurut responden dipilih dengan memberi tanda silang $(\mathrm{X})$ pada alternatif jawaban yang dianggap sesuai dengan pilihan respoden.

Sebelum dilakukan analisis data maka peneliti melakukan uji validitas dan reliabilitas. Uji validitas pada penelitian ini dilakukan dengan dua teknik yaitu validasi ahli dan validasi dengan bantuan program SPSS versi 23. Sedangkan uji reliabilitas pada penelitian ini menggunakan model alpha dengan bantuan program SPSS versi 23 , untuk pengambilan keputusan suatu instrumen dikatakan reliabel jika nilai Cronbach Alpha lebih besar dari 0,6.

Teknik analisis data yang digunakan pada penelitian ini yaitu menggunakan teknik analisis deskriptif presentase dan analisis korelasional dengan menggunakan uji Rank Spearman. Teknik analisis deskriptif presentase digunakan untuk menguji kedua variabel pada penelitian ini, sedangkan analisis korelasional digunakan untuk mengetahui pengaruh antara variabel kompetensi kepribadian guru (X) terhadap pembentukan karakter siswa (Y). Untuk mengetahui nilai signifikansi antara variabel X dan Y peneliti menggunakan bantuan program SPSS versi 23. Apabila nilai sig. < 
0,05 maka H1 di terima dan H0 di tolak. Namun, jika nilai sig. > 0,05 maka H0 di terima dan $\mathrm{H} 1$ di tolak.

\section{HASIL DAN PEMBAHASAN}

Data hasil penelitian meliputi hasil uji validitas dan reliabilitas kuesioner/angket, hasil uji deskriptif masing-masing variabel yaitu $\mathrm{X}$ dan $\mathrm{Y}$, serta hasil uji korelasi dua variabel $\mathrm{X}$ dan Y. Adapun hasil penelitian sebagai berikut:

\section{a. Uji Validitas dan Reliabilitas In- strumen Penelitian pada Variabel Kompetensi Kepribadian Guru (X) dan Karakter Siswa (Y)}

Uji validitas merupakan suatu uji yang dilakukan guna menunjukkan sejauh mana suatu alat ukur tersebut benar-benar cocok atau sesuai dengan alat ukur yang diinginkan (Sugiyono, 2015: 173).

Validasi pada penelitian ini dilakukan dengan menggunakan dua cara yaitu validasi ahli dan validasi dengan bantuan program SPSS Versi 23. Berdasarkan hasil validasi ahli yang dilakukan oleh kedua validator yaitu Dr. Muhammad Thamri Hidayat, M.Kes dan Mustofa, S.Pd., MA menunjukkan bahwa kuesioner komptensi kepribadian guru (X) memperoleh rata-rata sebesar 3,76 (4) yang artinya berada pada kategori sangat baik. Sedangkan kuesioner karakter siswa memperoleh nilai rata-rata dari kedua validator sebesar 3,77(4) yang artinya berada pada kategori sangat baik. Kategori tersebut didasarkan pada penilaian skala likert, dimana nilai 4 berada pada kategori sangat baik, 3 baik, 2 cukup, 1 kurang.

Setelah melalui uji validitas ahli maka peneliti melakukan uji validitas dengan bantuan program SPSS Versi 23, dengan menyebar kuesioner pada 25 responden yang dianggap memiliki karakteristik yang sama dengan responden yang sesungguhnya. Hasil uji validitas menunjukkan bahwa dari 13 butir pertanyaan kuesioner kompetensi kepribadian terdapat 2 butir tidak valid karena $r$ hitung yang diperoleh $<$ r tabel yaitu 0,3961 . Sedangkan hasil uji validitas pada karakter siswa (Y) yang berjumlah 20 butir pertanyaan menunjukkan bahwa terdapat 3 butir tidak valid, dan sisanya yaitu 17 butir soal dianggap valid karena $r$ hitung yang diperoleh > $r$ tabel yaitu 0,3961.

Setelah dilakukan uji validitas, maka peneliti melakukan uji reliabilitas. Hasil menunjukkan bahwa kedua variabel pada penelitian ini dinyatakan reliabel, dimana variabel (X) memperoleh reliabilitas sebesar 0,837 dan karakter siswa (Y) memperoleh reliabilitas sebesar 0,810 , yang artinya nilai yang diperoleh kedua variabel berada pada rentang 0,810-1,00 berada pada kualifikasi sangat reliabel.

\section{b. Uji Deskriptif Kompetensi Kepribadian Guru (X) dan Karakter Siswa (Y)}

1) Kompetensi Kepribadian Guru di SD Negeri Margorejo VI/524 Surabaya

Berdasarkah hasil analisis rekapitulasi kuesioner pada 171 responden dapat dilihat pada gambar 4.1.

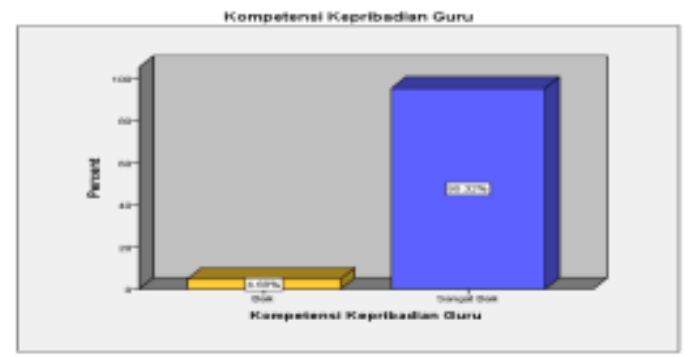


Gambar 4.1 Diagram Batang Kompetensi Kepribadian

Berdasarkan gambar 4.1 menunjukkan bahwa dari 171 responden, 8 responden menilai komptensi kepribadian guru baik sebesar 4,68\%. Sedangkan 163 responden menilai sangat baik sebesar 95,32\%.

Hasil uji deskriptif variabel kompetensi kepribadian guru $(\mathrm{X})$ dapat dilihat pada Tabel 4.6.

\begin{tabular}{|l|r|r|}
\multicolumn{3}{c}{ Statistics } \\
\hline & $\begin{array}{c}\text { Kompetensi } \\
\text { Kepribadian } \\
\text { Guru }\end{array}$ & $\begin{array}{c}\text { Kompetensi } \\
\text { Kepribadian } \\
\text { Guru }\end{array}$ \\
\hline N Valid & 171 & 171 \\
$\quad$ Missing & 0 & 0 \\
Mean & 92.82 & \\
Std. Devia- & 7.963 & \\
tion & \\
\hline
\end{tabular}

Dari Tabel 4.6 di atas diperoleh mean (rata-rata) sebesar 92,82 berada pada kategori sangat baik, kategori tersebut didasarkan pada kriteria analisis deskriptif presentase yang dikemukakan oleh Riduwan. Dimana 92,82\% berada pada rentang $76-100 \%$ yang artinya kompetensi kepribadian guru di SD Negeri Margorejo VI/524 Surabaya berada pada kualifikasi yang sangat baik. Dengan demikian guru di SD Negeri Margorejo VI/524 Surabaya dianggap telah menguasai seluruh dimensi kompetensi kepribadian sesuai dengan Permendiknas No.16 Tahun 2007.

2) Karakter Siswa di SD Negeri Margorejo VI/524 Surabaya

Berdasarkah hasil analisis rekapitulasi kuesioner pada 171 responden dapat dilihat pada gambar diagram 4.2.

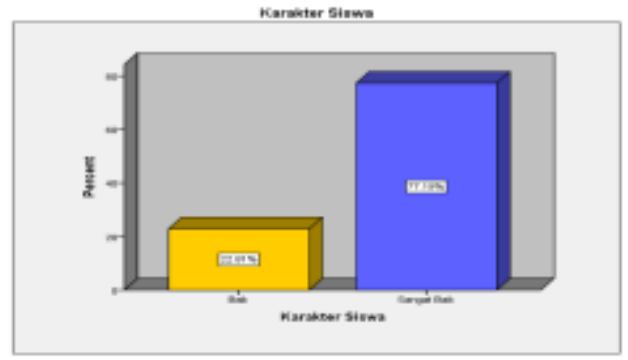

Gambar 4.2 Diagram Batang Karakter Siswa

Berdasarkan gambar 4.1 menunjukkan bahwa dari 171 responden, 39 responden menyatakan karakter siswa berada pada kategori baik sebesar 22,81\%. Sedangkan 132 responden menyatakan siswa dengan karakter sangat baik sebesar $77,19 \%$.

Hasil uji deskriptif variabel karakter siswa (Y) dapat dilihat pada Tabel 4.7 di bawah ini.

\begin{tabular}{|ll|r|r|}
\hline & & $\begin{array}{c}\text { Karakter } \\
\text { Siswa }\end{array}$ & $\begin{array}{c}\text { Karakter } \\
\text { Siswa }\end{array}$ \\
\hline $\mathrm{N}$ & Vali & 171 & 171 \\
& $\mathrm{~d}$ & & \\
& Miss & 0 & 0 \\
Mean ing & 84.34 & \\
Std. Deviation & 10.312 & \\
\hline
\end{tabular}

Berdasarkan Tabel

menunjukkan diperoleh mean (rata-rata) sebesar 84,34 berada pada kategori sangat baik, kategori tersebut didasarkan pada kriteria analisis deskriptif yang dikemukakan oleh Riduwan. Dimana $84,34 \%$ berada pada rentang $76-100 \%$ berada pada kategori sangat baik. Hasil yang diperoleh menunjukkan bahwa siswa di SD Negeri Margorejo VI/524 Surabaya memilik karakter yang sangat baik, artinya siswa di SD ini telah memiliki ke lima karakter utama yaitu Integritas, religius, nasionalis, mandiri, dan gotong royong.

\section{c. Uji Korelasi Kompetensi \\ Kepribadian Guru (X) dan \\ Pembentukan Karakter Siswa (Y)}


Berdasarkan hasil uji korelasi Rank Spearman antara variabel komptensi kepribadian dengan pembentukan karakter siswa menunjukkan bahwa koefisien korelasi Spearman rho yang diperoleh sebesar $0,436^{* *}$. Artinya besar korelasi atau pengaruh antara variabel kompetensi kepribadian guru (X) dan pembentukan karakter siswa (Y) ialah sebesar 0,436 atau berkorelasi rendah (cukup) dengan memperoleh nilai sig.(2tailed) signifikan sebesar $0,000<0,05$. Sehingga hipotesis pada penelitan ini $\mathrm{H}_{1}$ diterima yang artinya terdapat pengaruh antara kompetensi kepribadian guru dengan pembentukan karakter siswa.

Penelitian diatas menujukkan bahwa antara kompetensi kepribadian guru memiliki peranan penting dalam pembentukan karakter siswa. Guru sebagai sosok panutan/actor harus mempunyai kompetensi kepribadian, karena pembentukan karakter siswa sangat dipengaruhi oleh kompetensi kepribadian guru. Transformasi nilainilai luhur dapat diberikan melalui pendidikan, tetapi nilai-nilai tersebut akan efektif jika seirama dengan kepribadian yang dimiliki oleh guru. Artinya transformasi nilai akan gagal jika cerminan perilaku guru cenderung bertentangan.

\section{SIMPULAN}

Berdasarkan hasil penelitian yang telah dilakukan simpulan dari penelitian ini adalah:

1. Kompetensi kepribadian guru di SD Negeri Margorejo VI/524 Surabaya memperoleh nilai rata-rata sebesar $92,82 \%$ yang artinya kompetensi kepribadian guru di SD Negeri
Margorejo VI/524 Surabaya berada pada kategori sangat baik, hal tersebut menunjukkan bahwa guru di SD Negeri Margorejo VI/524 Surabaya telah menguasai dan mengimplementasikan kompetensi kepribadian yang sesuai dengan Permendiknas No.16 Tahun 2007,

2. Karakter siswa di SD Negeri Margorejo VI/524 Surabaya memperoleh nilai rata-rata sebesar 84,34 berada pada kategori sangat baik, artinya siswa di SD Negeri Margorejo VI/524 Surabaya telah memiliki kelima karakter sesuai dengan karakter yang dicanangkan Kementrian Pendidikan Nasional yaitu karakter integritas, religius, nasionalis, mandiri, dan gotong royong.

3. Kompetensi kepribadian guru memiliki pengaruh cukup kuat terhadap pembentukan karakter siswa di SD Negeri Margorejo VI/524 Surabaya, pengaruh tersebut terlihat dari hasil korelasi sebesar 0,436 atau berkorelasi rendah (cukup) dengan signifikan sebesar $0,000<0,05$ yang artinya terdapat pengaruh yang cukup/rendah dan signifikan antara kompetensi kepribadian guru dengan pembentukan karakter siswa di SD Negeri Margorejo VI/524 Surabaya.

\section{SARAN}

Berdasarkan simpulan yang diuraikan tersebut, maka saran yang dapat diberikan oleh peneliti

1. Peneliti diharapkan dapat melakukan penelitian lebih dalam tentang pembentukan karakter siswa, karena masih banyak berbagai faktor lain yag dapat 
membentuk serta mempengaruhi karakter siswa di Sekolah Dasar.

2. Guru disarankan untuk lebih berusaha meningkatkan penguasaan kompetensi kepribadian, sehingga guru dapat mengoptimalisasikan pembentukan karakter siswa di Sekolah Dasar.

3. Bagi peneliti lain yang hendak melakukan penelitian yang serupa agar memperhatikan kendala-kendala yang dialami peneliti sebelumnya untuk dijadikan sebagai bahan pertimbangan guna perbaikan dan penyempurnaan penelitian yang akan dilaksanakan.

4. Sekolah diharapkan mampu meningkatkan serta meperbaiki kompetensi kepribadian yang dimiliki oleh setiap guru, agar sekolah dapat melakukan pembentukan karakter siswa di Sekolah Dasar secara maksimal.

\section{DAFTAR PUSTAKA}

Andriyani, F. (2017). Membangun Kompetensi Guru Sebagai Upaya Membentuk Generasi Yang Utuh. Jurnal Pendidikan Guru Sekolah Dasar, 1-11.

Anwar, S. (2011). Studi Realitas Tentang Kompetensi Kepribadian Guru Pendidikan Agama Islam Sekolah Menengah Atas di Kabupaten Bandung Barat. Jurnal Pendidikan Agama Islam-Ta'lim, Vol.9 No.2, 145-159.

Asmani, Jamal Ma'mur. (2013). Buku Panduan Internalisasi Pendidikan Karakter di Sekolah. Jogjakarta: Diva Press.

Azzet, Akhmad Muhaimin. (2014). Urgensi Pendidikan Karakter di
Indonesia. Jogjakarta: Ar-Ruzz Media.

Chatib, M. (2016). Gurunya Manusia. Bandung: Kaifa.

Dispendik. (2018). Rena Mangan Gotri, Pendidikan Karakter Versi Kota Surabaya.

https://dispendik.surabaya.go.id.

diakses pada 25 Maret 2019.

Dispendik. (2019). Portal Informasi Sekolah Kota Surabaya. https://profilsekolah.dispendik.go.id. diakses pada 11 April 2019.

Djamarah, S. B. (2012). Prestasi Belajar dan Kompetensi Guru. Surabaya: Usaha Nasional.

Gunawan, I. (2016). Pengantar Statistika Inferensial. Jakarta: PT RajaGrafindo Persada.

Hasbullah. (2015). Dasar-Dasar Ilmu Pendidikan. Jakarta: PT RajaGrafindo Persada.

Kemendikbud. (2018). Konsep dan Pedoman Penguatan Pendidikan Karakter Tingkat Sekolah Dasar dan Sekolah Mengah Pertama. Jakarta: Kementrian Pendidikan dan Kebudayaan Republik Indonesia.

Kemendikbud. (2018). Rubrik Penilaian Karakter. Jakarta: Pusat Penilaian Pendidikan Badan Penelitian Dan Pengembangan Kementrian Pendidikan Dan Kebudayaan.

Kurniawan, Syamsul. (2017). Pendidikan Karakter Konsepsi \& Implementasinya secara Terpadu di Lingkungan Keluarga, Sekolah, Perguruan Tinggi, \& Masyarakat. Yogyakarta: Ar-Ruzz Media. 
Muhson. (2013). Bahan Ajar Metodologi Penilitian: Analisis Kuantitatif. Yogyakarta: UNY.

Payong, M. R. (2011). Sertifikasi Profesi Guru Konsep Dasar, Problematika, dan Implementasinya. Jakarta: PT Indeks.

Permendiknas. (2007). Kualifikasi Akademik dan Kompetensi Guru. Jakarta: Kemendiknas.

Riduwan. (2008). Skala Pengukuran Variabel-Variabel Penelitian. Bandung: Alfabeta.

Rochman, C., \& Gunawan, H. (2012). Pengembangan Kompetensi Kepribadian Guru; Menjadi Guru yang Dicintai dan Diteladani oleh Siswa. Bandung: Nuansa Cendekia. Salahudin, A., \& Alkrienciehie, I. (2013). Pendidikan Karakter Pendidikan Berbasis Agama \& Budaya Bangsa. Bandung: Pustaka Setia.

Salim, H. N., \& Sarwono, J. (2017). Prosedur-Prosedur Populer Statistik Untuk Analisis Data Riset Skripsi. Yogyakarta: Gava Media.

Samani, M., \& Hariyanto. (2012). Pendidikan Karakter. Bandung: PT Remaja Rosdakarya.

Saputri, D. M. (2017). Kompetensi Kepribadian Guru Dalam Membentuk Karakter Siswa 3A SDN 1 Gedongkiwo Yogyakarta. Jurnal Pendidikan, 1-13.

Sarwono, J. (2006). Metode Penelitian Kuantitatif \& Kualitatif. Yogyakarta: Graha Ilmu.

Sugiyono. (2015). Metode Penelitian Pendidikan Pendekatan Kuantitatif Kualitatif dan $R \& D$. Bandung: Alfabeta.
Sugiyono. (2016). Metode Penelitian Kuantitatif, Kualitatif dan $R \& D$. Bandung: Alfabeta.

Sugiyono. (2017). Metode Penelitian Kuantitatif, Kualitatif, dan $R \& D$. Bandung: Alfabeta.

Suharsaputra, U. (2014). Metode Penelitian Kuantitatif, Kualitatif, dan Tindakan. Bandung: PT Refika Aditama.

Suprihatiningrum, J. (2013). Guru Profesional Pedoman Kinerja, Kualifikasi, \& Kompetensi Guru. Jogjakarta: Ar-Ruzz Media.

Suyanto \& Jihad, Asep. (2013). Menjai Guru Profesional Strategi Meningkatkan Kualifikasi dan Kualitas Guru di Era Global. Jakart: Esensi.

Tamsil, M., Syafiq, M., \& Savira, S. I. (2011). Bentuk, Penyebab, dan Dampak Dari Tindakan Kekerasan Guru Terhadap Siswa Dalam Interaksi Belajar Mengajar Dari Perspektif Siswa Di SMP Kota Surabaya: Sebuah Survey. Jurnal Psikologi, Vol.1, No.2, 63-74.

Wibowo, A., \& Hamrin. (2012). Menjadi Guru Berkarakter Strategi Membangun Kompetensi \& Karakter Guru. Yogyakarta: Pustaka Pelajar.

Widyaningsih. (2015). Pengaruh Kompetensi Kepribadian Guru Terhadap Disiplin Siswa Kelas V SD Se-Gugus 1 Sidoarum Godean Sleman Tahun Ajaran 2015/2016. Jurnal Pendidikan, Vol 1, No 3. Dipetik November 20, 2018, dari http://repository.upy.ac.id/341/1/Ju rnal\%2520Widyaningsih.pdf 
Indah Tri Agustin, Nafiah - Pengaruh Kompetensi Kepribadian Guru Terhadap Pembentukan Karakter Siswa di SD

Widyastono, H. (2010). Penyelenggaraan

Pendidikan Karakter Melalui

Optimalisasi Pelaksanaan

Kurikulum Tingkat Satuan

Pendidikan. Jurnal Pendidikan dan

Kebudayaan, Vol 16, 290-299.

Zubaedi. (2011). Desain Pendidikan

Karakter: Konsepsi dan

Aplikasinya dalam Lembaga

Pendidikan. Jakarta: Kencana

Prenada Media Group 
Education and Human Development Journal Volume 4. Nomor 2. September 2019 